\title{
RELEVANSI PENDIDIKAN ISLAM BERBASIS ILMU SOSIAL PROFETIK TERHADAP PENGEMBANGAN KURIKULUM 2013 DI MADRASAH
}

\author{
Tatag Satria Praja1), Muslih2) \\ Universitas Muhammadiyah Lamongan, Indonesia ${ }^{1}$ \\ Institut Pesantren Sunan Drajat Lamongan, Indonesia ${ }^{2}$ \\ Email: praja684@gmail.com¹, Muslihalawi@Insud.ac.id²
}

Dikirim: 20 April 2021 | Direvisi: 28 Juni 2021 | Dipublikasikan: 31 Juli 2021

\begin{abstract}
Abstraksi: Islamic education is not just a process of inculcating moral values to fortify negative access, but how the instilled moral values are able to play a role as the strength of Islam to get out of poverty, ignorance, social and cultural backwardness. Today, the current of modernization gives birth to a culture that leads to liberalization, rationalization, and materialization. This article is a literature review that tries to explore the socio-cultural values that are integrated in the realm of Islamic education that are inseparable from one another. So that Islamic education can adapt and adopt local cultural values of course that do not conflict with the essence of Islamic teachings, so that Islamic education can be easily accepted and grounded in the reality of the society where Islamic education is taught. Islamic education using culture is needed as part of forming the identity of a Muslim. Prophetic social science is an alternative choice of Islamic culture format introduced by Kuntowijoyo through three domains, humanization (amar ma'rūf), liberation (nahyī mungkar), and transcendence, related to the word of Allah Q.S. Ali-'Imrān [3]:110. Related to these interests, changes are also needed in the National Education System related to the curriculum, in this case the 2013 curriculum in madrasas.

Kata kunci: Modernization of Islamic education; prophetic; curriculum 2013; Madrasah.
\end{abstract}

\section{Pendahuluan}

Pendidikan Islam pada intinya merupakan sistem meningkatkan kualitas hidup manusia. Dalam konteks sosio-historis manusia tidak bisa lepas dari proses pendidikan, dimana proses pendidikan berlangsung sepanjang hayat. Dalam merespon perkembangan zaman, pendidikan Islam dihadapkan tantangan era globalisasi yang memberikan kesan sangat marketable, lulusan pendidikan yang siap pakai (ready for use) dan pengaruhnya pada standar ekonomi. ${ }^{1}$ Padahal pendidikan memiliki peran sebagai sarana menciptakan manusia unggul. Pendidikan memiliki tugas menciptakan output yang dapat bersaing di zaman modern sekarang ini. Tidak terkecuali pendidikan Islam, idealnya lembaga pendidikan Islam harus memiliki output pendidikan unggul. Kenyataannya, bahwa sekolah berciri khas Islam seperti madrasah kalah bersaing dengan sekolah umum. Masyarakat lebih mempercayakan sekolah umum dalam mendidik anaknya dan identik dengan pendidikan second class dan tidak maju. ${ }^{2}$

\footnotetext{
1 Abuddin Nata, Sosiologi Pendidikan Islam (Jakarta: Rajawali Press, 2014), 292.

${ }^{2}$ A. Zayadi, Dirjen Kelembagaan Agama Islam (Jakarta: Dirjen Kelembagaan Agama Islam, 2005), 2-3.
} 
Dewasa ini, arus modernisasi melahirkan kebudayaan yang mengarah kepada liberalisasi, rasionalisasi, materialisasi. Akibatnya, banyak masyarakat terjerumus dalam perilaku amoral yang tidak bertanggung jawab. ${ }^{3}$ Menurut Richard S dalam The Culture of Cynicism: American Morality in Decline, bahwa gambaran masa depan masyarakat modern berbagai perilakunya amoral, individual dan mementingkan kekuatan (fisik) jauh dari makna (spiritual). ${ }^{4}$ Lebih memilukan, kasus seorang oknum dari kepala sekolah dilaporkan ke Mapolda DIY, lantaran mencabuli salah seorang siswi kelas 3 MTs di Bantul. ${ }^{5}$ Kriminalitas, kemerosotan akhlak, pola kehidupan melupakan Tuhan menjadi fenomena nyata. Fakta ini menggambarkan seolah-olah agama tidak fungsional dalam masyarakat dan tidak mampu juga menyelesaikan problematika kehidupan serta kemanusiaan. Menurut Kuntowijoyo, proses industrialisasi dan modernisasi akan selalu mengancam nilai-nilai agama (termasuk di dalamnya nilai-nilai kemanusiaan). ${ }^{6}$

Pada hakekatnya pendidikan Islam bukan sekedar proses penanaman nilai moral untuk membentengi diri dari akses negatif dan bukan sekedar strategi definitif yang hanya ingin untuk menyelamatkan pemikiran dari pencemaran dan kerusakan moral yang ditimbulkan gagasan Barat melalui ilmu modern, terutama yang dianggap akan mengancam moralitas Islam. Tetapi yang tidak kalah penting, bagaimana nilai-nilai moral yang telah ditanamkan dalam pendidikan Islam berperan aktif sebagai kekuatan bagi umat Islam untuk keluar dari himpitan kemiskinan, kebodohan dan keterbelakangan sosial serta budaya. ${ }^{7}$ Perlu kiranya reformulasi visi, misi, kurikulum serta seluruh komponen berkaitan dengan proses pendidikan diselaraskan dengan tuntutan era sekarang ini, sebagai suatu bentuk pertanda akan perubahan zaman, sosial, dan kebudayaan, kesemuanya selalu tetap teguh pada nilai-nilai universalitas ajaran Islam.

Pendidikan Islam dengan menggunakan kebudayaan diperlukan sebagai pembentukan jati diri muslim yaitu lewat lingkungan dengan simbol-simbol edukatif-religius yang dimilikinya. Dimensi profetik adalah alternatif pilihan dalam format budaya Islam yang diperkenalkan oleh Kuntowijoyo melalui tiga ranah, humanisasi ('amar ma'rüf), liberasi (nabyz mungkar) dan juga transendensi (tu’minūnabilläh). Hal ini berkaitan juga dengan firman Allah dalam Q.S. Āli-'Imrān [3] : 110. ${ }^{8}$ Upaya

\footnotetext{
3 Azyumardi Azra, Paradigma Baru Pendidikan Nasional, Rekonstruksi dan Demokratisasi (Jakarta: Buku Kompas, 2002$), 19$.

${ }^{4}$ Ali Formen Yudha, Gagap Spiritual: Dilema Eksistensi di Tengah Kecamuk Sosial (Yogyakarta: Kutub, 2004), iv-v.

5 Retnowati, Kanit Perlindungan Perempuan dan Anak (PPA) Polda DIY saat ditemui Kompas.com, senin (16/05/2016). Diakses di web. Kompas.com pada hari rabu, 25 mei 2016.

${ }^{6}$ Kuntowijoyo, Paradigma Islam: Interpretasi Untuk. Aksi (Bandung : Mizan, 1991), 172.

${ }^{7}$ Fazlur Rahman, Islam dan Modernitas Tentang Transformasi Intelektual, terj. Ahsin Muhammad (Bandung: Pustaka Pelajar, 1995), 34-35.

${ }^{8}$ Kuntowijoyo, Paradigma Islam: Interpretasi Untuk. Aksi..., 288.
} 
menanamkan dan memupuk nilai humanisasi, liberasi, transendensi lebih efektif dilakukan melalui proses pendidikan, guna membentuk profil manusia yang dewasa secara pola pikir, sikap, tingkah laku, berakhlakul karimah. Salah satu komponen penting pendidikan adalah kurikulum. Kurikulum sebagai acuan atau program guna mencapai tujuan pendidikan berpengaruh besar dalam membentuk output yang berkualitas. ${ }^{9}$

Terkait kepentingan tersebut diperlukan perubahan mendasar dalam Sistem Pendidikan Nasional berkaitan dengan kurikulum yang dengan sendirinya menuntut berbagai perubahan pada komponen pendidikan lainnya. Kurikulum berbasis karakter dan kompetensi merupakan salah satu konstribusi untuk memecahkan berbagai persoalan bangsa, khususnya dalam bidang pendidikan. Karena, merupakan langkah yang positif ketika pemerintah melakukan revitalisasi terkait pendidikan karakter pada seluruh jenis dan jenjang pendidikan, termasuk juga dalam pengembangan kurikulum 2013 di madrasah. ${ }^{10}$ Ketetapan yang tercantum di dalam rencana strategis Kementerian Agama memperlihatkan arah baru yang jelas bahwasanya kurikulum 2013 yang dikembangkan memperdulikan aspek-aspek potensi manusia terkait dengan domain sikap untuk mengembangkan soft-skill yang seimbang dengan bard-skills, seiring dengan ruh pendidikan Agama Islam itu sendiri. ${ }^{11}$ Melalui pengembangan kurikulum 2013 di madrasah, diharapkan menjadi bangsa bermartabat dan memiliki nilai tambah, sehingga mampu bersaing.

\section{Metode Penelitian}

Penelitian ini merupakan penelitian kualitatif dan bersifat induktif. Penelitian dikategorikan penelitian kepustakaan (library research) yaitu suatu penelitian yang mengfokuskan pembahasan pada literatur-literatur atau sumber dokumen yang relevan. ${ }^{12}$ Penelitian menggunakan pendekatan (filosofissosilogis). Pendekatan filosofis yaitu pendekatan dengan cara berfikir menurut logika dengan bebas kedalamnya sampai pada dasar persoalan atau pengetahuan yang mendalam tentang rahasia dan tujuan dari segala sesuatu. ${ }^{13}$ Sedangkan pendekatan sosiologis adalah suatu landasan kajian sebuah studi atau penelitian untuk mempelajari hubungan antara manusia dalam kelompok dan sosialnya. ${ }^{14}$ Metode pengumpulan data menggunakan metode dokumenter, yaitu mencari data mengenai hal-hal atau variabel yang berupa catatan, buku, surat kabar, majalah, prasasti, notulen rapat dan sebagainya. ${ }^{15}$ Sumber data primer terkait dengan karya dan pemikiran Kuntowijoyo serta pedoman Pengembangan

\footnotetext{
${ }^{9}$ Imam Barnadib, Arah Perspektif Baru Pendidikan (Jakarta: Depdikbud, 1988), 24.

10 Menteri Agama Republik Indonesia, Peraturan Menteri Agama Republik Indonesia, No. 000912 Tahun 2013 Tentang

Kurikulum Madrasah 2013 Mata Pelajaran Pendidikan Agama Islam dan Bahasa Arab (Jakarta: MENAG RI, 2013$), 1$.

${ }^{11}$ Ibid., 3.

12 Noeng Muhadjir, Metode Penelitian Kualitatif (Yogyakarta: Rakesarasin,1996), 158.

13 Anton Bekker, Metode Penelitian Filsafat (Yogyakarta: Kanisius, 1990), 15-16.

${ }^{14}$ Made Pidarta, Landasan Kependidikan: Stimulus Ilmu Pendidikan Bercorak Indonesia (Jakarta: Rineka Cipta, 2009$), 46$.

${ }^{15}$ Sanafiah Faisal, Metode Penelitian Pendidikan (Surabaya: Usaha Nasional, 1993), 133.
} 
Kurikulum 2013 Kemenag RI. Sedangkan sumber data sekunder adalah data yang dikumpulkan untuk maksud selain menyelesaikan masalah yang sedang dihadapi, data ini dapat ditemukan dengan cepat. ${ }^{16}$ Metode analisis data yang digunakan adalah analisis isi atau dokumen (content or ducumen analysis), analisis yang ditujukan kepada dokumen-dokumen yang validitas dan juga keabsahannya terjamin, termasuk buku teks baik bersifat teoritis maupun empiris. Dokumen tersebut dianalisis untuk mengetahui makna, kedudukan dan hubungan berbagai konsep yang digagas untuk mengetahui manfaat, hasil atau dampak konsep tersebut. ${ }^{17}$

\section{Kajian tentang Pendidikan Islam}

Pendidikan Islam secara etimologi berasal dari bahasa Arab yaitu al-Tarbiyyah, al-Ta'dib, alTa'lim. Pengertian pertama at-tarbiyah berasal dari kata Rabb, memiliki makna tumbuh, berkembang, memelihara, mengatur dan menjaga eksistensi. Rabb berarti Tuhan dan Murrabi berarti pendidik, berasal dari akar kata yang sama. Maka Allah adalah pendidik yang Maha agung. Dalam konteks yang lebih luas, pengertian pendidikan Islam dalam arti at-tarbiyah terdiri atas empat unsur, yaitu: memelihara serta menjaga fitrah peserta didik menjelang dewasa, dan mengembangkan seluruh potensi, mengarahkan seluruh fitrah dan juga melaksanakan pendidikan bertahap. ${ }^{18}$ Berdasarkan hasil seminar pendidikan Islam tahun 1960, bahwa pendidikan Islam adalah upaya untuk bimbingan seseorang terhadap pertumbuhan rohani dan jasmani menurut ajaran Islam dengan hikmah mengarahkan, mengajarkan, melatih, mengasuh, dan juga mengawasi berlakunya seluruh ajaranajaran Islam. ${ }^{19}$

Tujuan pendidikan Islam adalah membina peserta didik menjadi hamba yang selalu beribadah kepada Allah mencakup segala amal, pikiran maupun juga perasaan. Ibadah adalah jalan hidup yang mencakup seluruh aspek kehidupan serta segala yang dilakukan manusia baik perkataan, perbuatan, maupun perasaan bahkan bagian apa pun dari perilakunya dalam mengabdikan dirinya hanya kepada Allah. ${ }^{20}$ Kurikulum yang baik dalam mencapai tujuan pendidikan Islam adalah yang bersifat integreted, komprehensif dan menjadikan Al-Qur'an serta hadis sebagai sumber utama dalam penyusunan. Inti kurikulum pendidikan Islam yaitu ketauhidan, karena ketauhidan dapat mewujudkan tata dunia harmonis, kosmos penuh tujuan, persamaan sosial, persamaan kepercayaan dalam segala aktifitas dan kebebasan $^{21}$

\footnotetext{
16 Ibid., 138.

${ }^{17}$ Nana Syaodih Sukmadinata, Metode Penelitian Pendidikan..., 81.

${ }^{18}$ Samsul Nizar, Filsafat Pendidikan Islam: Pendekatan Historis, Teoritis dan Praktis (Jakarta: Ciputat Press, 2002), 25-26.

19 Ibid., 48.

20 Ahmad Mutohar dan Nurul Anam, Manifesto Modernisasi Pendidikan Islam dan Pesantren (Yogyakarta: Pustaka Pelajar, 2013), 54.

${ }^{21}$ Ahmad Mutohar dan Nurul Anam, Manifesto Modernisasi..., 82.
} 
Metode pendidikan Islam, antara lain: Metode hukuman dan ganjaran, ceramah, metode diskusi, tingkah laku dan teladan, nasehat, kisah-kisah, dan pembiasaan dll. ${ }^{22}$ Metodologi pendidikan Islam juga haruslah didasarkan tiga hal, yaitu: didasakan pada pandangan bahwa manusia dilahirkan dengan potensi bawaan tertentu, didasarkan pada karaktersitik masyarakat, dan didasarkan juga pada learning competency dimana peserta didik akan memiliki seperangkat pengetahuan, keterampilan, dan wawasan. $^{23}$

Pendidik merupakan spiritual father. Menjadi pendidik hendaknya memiliki sifat-sifat: zuhud, bersih (menjauhi dosa), ikhlas, berpengetahuan luas, memberikan teladan, loyal, bertanggung jawab, harus mengetahui tabiat peserta didik dan harus menguasai pelajaran yang diajarkannya. ${ }^{24}$ Sedangkan peserta didik adalah makhluk Allah yang memiliki fitrah jasmani dan rohani, maka kedua fitrah tersebut haruslah dikembangkan. ${ }^{25}$ Adapun syarat-syarat evaluasi dalam pendidikan Islam, antara lain: haruslah reliabel, valid, objektif, diskriminatif, komprehensif. ${ }^{26}$

Lingkungan pendidikan Islam berada pada lingkungan keluarga, sekolah dan masyarakat. Sedangkan lingkungan dari prespektif pendidikan Islam adalah suatu yang ada di sekeliling tempat anak melakukan adaptas. ${ }^{27}$

\section{Konsep tentang Ilmu Sosial Profetik}

Istilah profetik dalam term keilmuan sudah diperkenalkan Kuntowijoyo melalui konsep Ilmu Sosial Profetik. Bagi Kuntowijoyo, Ilmu Sosial Profetik (ISP) tidak hanya menjelaskan dan mengubah fenomena sosial tapi juga memberi petunjuk kearah mana transformasi itu dilakukan, untuk apa dan untuk siapa. Karena itu, ilmu sosial profetik bukan sekedar mengubah berdasarkan cita-cita etik dan profetik saja. Dalam pengertian ini, ilmu sosial profetik secara sengaja memuat kandungan nilai dari cita-cita yang diidamkan masyarakatnya. ${ }^{28}$

Profetik dalam hal ini dikembangkan Kuntowijoyo, yang mengacu pada konteks Al-Qur'an, dalam Q.S. Ali-Imran [3]: 110. Dalam ayat tersebut nilai-nilai profetik meliputi tiga hal, yaitu: 'amar ma'rüf (humanisasi), nahyĩ mungkar (liberasi), imān billah (transendensi). ${ }^{29}$ Dalam ayat tersebut terdapat empat konsep: umat terbaik, aktivisme sejarah, pentingnya kesadaran, dan etika profetik, ayat tersebut

\footnotetext{
22 Ibid.,193-197.

${ }^{23}$ Hujair AH. Sanaky, Paradigma Pendidikan Islam Membangun Masyarakat Madani Indonesia (Yogyakarta: Safiriah Insaniah Press, 2003), 191.

${ }^{24}$ Abd. Rachman Assegaf, Filsafat Pendidikan Islam: Paradigma Pendidikan Hadhari Berbasis Integratif-Interkonektif (Jakarta: Raja Grafindo Persada, 2011), 111-112.

${ }^{25}$ Hartono Agung, Perkembangan Peserta Didik (Jakarta: Rineka Cipta, 1999), 16-17.

${ }^{26}$ Ibid., 294-295.

${ }^{27}$ Sama'un Bakry, Mengagas Konsep Ilmu Pendidikan Islam (Bandung: Pustaka bani Quraisy, 2005), 97.

${ }^{28}$ Kontowijoyo, Paradigma Islam: Interpretasi untuk. Aksi..., 289.

${ }^{29}$ Ibid., 290.
} 
mengandung etika yang berlaku umum atau untuk siapa saja baik, individu maupun organisasi atau kolektifitas. $^{30}$

Secara definitif, profetik dapat dipahami sebagai seperangkat teori yang tidak hanya mendeskripsikan dan mentransformasikan gejala sosial, namun lebih dari itu, diharapkan dapat mengarahkan perubahan atas dasar cita-cita etik dan profetik. ${ }^{31}$ Berdasarkan pemapaparan di atas, dapat disimpulkan bahwa profetik adalah realitas abstrak yang terdapat pada sifat kenabian sebagai manusia ideal secara spiritual-individual, diimplementasikan dalam 'amar ma'rüf (humanisasi), nabyì mungkar (liberasi) dan tu'minünabilläh (transendensi).

Pilar-Pilar Profetik, antara lain: transendesi diartikan sebagai ikatan spiritualitas antara manusia dengan Tuhannya. Hubungan dan pengalaman spiritual tersebut bersifat individual dan sulit dikomunikasikan dalam bahasa verbal kepada orang lain, pilar transendensi menjadi acuan bagi setiap tindakan muslim, sebab semangat ilmiah pada kenyataanya mengalir dari kesadaran akan tauhid. ${ }^{32}$ Liberasi dalam pemaknaan profetik bagian dari nabyi mungkar. Liberasi diartikan sebagai pembebasan terhadap semua yang berkonotasi terhadap signifikasi sosial. ${ }^{33}$ Humanisasi diartikan upaya memanusiakan manusia, yaitu menghilangkan kebendaan, ketergantungan, kekerasan dan kebencian dari manusia, proses mengembalikan jati diri manusia.

\section{Pengembangan Kurikulum 2013 di Madrasah}

Hakikat Kurikulum 2013 menurut Undang-Undang Nomor 20 Tahun 2003 tentang Sistem Pendidikan Nasional, bahwa kurikulum merupakan seperangkat rencana dan pengaturan mengenai tujuan, isi, bahan pelajaran, serta cara yang akan digunakan sebagai pedoman penyelenggaraan kegiatan pembelajaran untuk mencapai tujuan pendidikan. ${ }^{34}$ Berdasarkan pengertian tersebut, ada dua dimensi kurikulum, yaitu: pertama adalah rencana dan pengaturan mengenai tujuan, isi, dan juga bahan pelajaran. Kedua adalah cara yang digunakan dalam kegiatan pembelajaran.

Prinsip-prinsip dalam penyusunan kurikulum madrasah, antara lain: peningkatan iman, takwa dan akhlak mulia, kebutuhan kompetensi untuk masa depan, peningkatan potensi, kecerdasan, minat, keragaman potensi, karakteristik daerah dan lingkungan, pembangunan daerah dan nasional, tuntutan dunia kerja, perkembangan IPTEK dan seni, agama, dinamika perkembangan global, memperkokoh rasa persatuan dan nilai kebangsaan, keadaan sosial-budaya masyarakat, kesetaraan gender, serta karakteristik satuan pendidikan. ${ }^{35}$

\footnotetext{
30 Ibid., 92.

${ }^{31}$ Kuntowijoyo, Islam Sebagai Ilmu: Epistemologi, Metodologi..., 7-8.

32 Mohammad Roqib, Prophetic Education: Kontekstualisasi Filsafat..., 78.

33 Ibid., 369.

34 Syamsul Huda Rohamdi, Pengmebangan Kurikulum Pendidikan Agama Islam (Yogyakarta: Araska, 2013), 9.

35 Direktur Pendidikan Madrasah, Modul Inti Panduan Pengembangan Kurikulum Madrasah 2013 (Jakarta: KEMENAG RI, 2014), 47-48.
} 
Tujuan pengembangan kurikulum 2013 adalah untuk mempersipakan manusia Indonesia (SDM), agar bisa memiliki kemampuan hidup sebagai pribadi dan warga negara yang beriman produktif, kreatif, inovatif, afektif serta mampu berkontribusi pada kehidupan bermasyarakat, berbangsa dan bernegara. ${ }^{36}$ Pengembangan kurikulum 2013 dilakukan karena adanya berbagai tantangan yang dihadapi, yaitu: tantangan internal, terkait dengan tuntutan pendidikan yang mengacu pada 8 Standar Nasional Pendidikan, tantangan eksternal terkait dengan arus globalisasi, penyempurnaan pola pikir, penyempurnaan tata kolola, Penguatan materi, dilakukan dengan pendalaman dan perluasan materi yang relevan bagi peserta didik. ${ }^{37}$

Landasan Pengembangan Kurikulum 2013, landasan filosofis yaitu pendidikan yang berakar pada budaya bangsa untuk membangun kehidupan bangsa masa kini dan mendatang, pendidikan ditunjukkan untuk mengembangkan kecerdasan intelektual dan kecemerlangan akademik, dan pendidikan juga membangun kehidupan masa kini dan masa depan. Dan landasan teoritis kurikulum dikembangkan atas teori pendidikan berdasarkan standar dan berdasarkan teori kurikulum berbasis kompetensi. Kurikulum 2013 menganut: pembelajaran dilakukan dalam bentuk proses yang dikembangkan berupa pembelajaran madrasah, kelas, masyarakat, dan pengalaman belajar langsung harus sesuai latar belakang, karakteristik, serta kemampuan awal peserta didik.

\section{Pendidikan Islam Berbasis Ilmu Sosial Profetik}

Letak perbedaan pendidikan Islam berbasis profetik dengan pendidikan Islam selama ini adalah objektifikasinya. Pendidikan Islam yang ada selama ini lebih kepada islamisasi ataupun doktrinisasi, tetapi pendidikan Islam berbasis profetik lebih pada objektifikasinya. Seperti ajaran tentang menyantuni orang miskin dan anak yatim tidak hanya berlaku bagi orang Islam saja, namun juga orang di luar Islam. ${ }^{38}$ Dalam hal ini, peneliti menjelaskan pendidikan Islam berbasis ilmu sosial profetik, sebagaimana berikut:

Pendidikan profetik sendiri merupakan pendidikan yang mengambil inspirasi Nabi Muhammad. Prinsipnya mengutamakan integrasi, sehingga tujuan dunia dan akhirat dapat tercapai, karena pada dasarnya peran pendidikan Islam untuk mencapai kebahagiaan dunia-akhirat. Penelitian ini, menggunakan konsep profetik sebagaimana dikembangkan oleh Kuntowijoyo dalam Ilmu sosial profetik, yaitu yang berlandaskan Q.S. Āli-'Imrān [3]: 110. ${ }^{39}$ Dari sudut pandang filsafat, pendidikan Islam berbasis ilmu sosial profetik upaya mendialogkan manusia, Tuhan, dan alam tentang hakekat kebenaran berdasarkan wahyu yang menginternal dalam diri Nabi, dikomunikasikan kepada manusia

${ }^{36}$ Menteri Agama Republik Indonesia, Peraturan Menteri Agama..., 6.

${ }^{37}$ Dirman dan Cicin Juarsih, Pengembangan Kurikulum..., 7-8.

${ }^{38}$ Jalaluddin Rakhmat, Islam Aktual: Refleksi Sosial Cendekiawan Muslim (Bandung: Mizan, 1992), 97.

${ }^{39}$ Kuntowijoyo, Muslim Tanpa Masjid: Esai-Esai Agama, Budaya..., hlm. 357. 
serta alam agar kebenaran menjadi mungkin direalisasikan dalam kehidupan, sehingga tercipta manusia terbaik dengan kehidupan sejahtera. ${ }^{40}$

Didefinisikan, pendidikan Islam berbasis ilmu sosial profetik adalah transfer knowledge and values untuk mengesakan Allah yang dilakukan secara kontinyu dan dinamis disertai pemahaman bahwa dalam diri manusia terdapat kelebihan dan juga kelemahan yang menunjukkan adanya campur tangan yang transenden. Pemahaman ini terus berdialog dengan Tuhan yang transenden serta alam yang secara internal berwujud self-correction atau mubäsabah an-nafs, secara eksternal berwujud 'amar ma'rüf (humanisasi) dan juga nabyi mungkar (liberasi).

Adapun prinsip pendidikan Islam berbasis ilmu sosial profetik, sebagaimana berikut: Prinsip integrasi (tauhid) memandang adanya wujud kesatuan dunia-akhirat, prinsip keseimbangan, prinsip persamaan dan pembebasan, prinsip kontinuitas dan berkelanjutan, dan prinsip kemaslahatan dan keutamaan. ${ }^{41}$

Urgensi ilmu sosial profetik dalam pendidikan Islam pada kehidupan kontemporer sekarang ini, antara lain: Merupakan tawaran menyangkut pentingnya pemahaman agama yang rasional, menawarkan kesadaran keberagaman pendapat, pemahaman, etnis, agama secara tulus, menekankan dinamika manusia agar tidak menyerah pada nasibnya (takdir), menekankan penguasaan IPTEK, dan upaya meraih kemajuan bersama Al-Qur'an dan Hadis. Adapun urgensinya bagi peserta didik, yaitu: peserta didik akan bisa sadar sebagai makhluk ciptaan Allah, cinta pada Allah, menjadi pembelajar sejati, mampu menghargai perbedaan dengan bijak, kontributif dalam tindakannya, dan peserta didik bermoral, jujur, ikhlas, saling menghormati, tidak sombong, suka membantu dengan sesama, tidak mengharap imbalan. ${ }^{42}$

Hakekat dari pendidikan Islam berbasis ilmu sosial profetik, antara lain: merupakan paradigma pendidikan Islam yang teosentris-antroposentris, mewujudkan peserta didik memiliki keseimbangan pribadi menyeluruh, menuntut perubahan yang permanen disertai dengan tujuan (sence of goal). Dimana dalam profetik menghendaki adanya transformasi menuju transendensi dengan proses humanisasi (memanusiakan manusia), kemudian liberasi (membebaskan manusia dari berbagai penindasan) dan didasarkan transendensi (membawa manusia beriman kepada Allah). ${ }^{43}$ Ketiga hal tersebut adalah visi profetik, maka ketiganya harus dijadikan tema pendidikan Islam. Pendidikan Islam haruslah menyertakan transendensi, sebab tanpa trensendensi tidak akan menjadi pendidikan Islam, karena Islam merupakan ikatan manusia dengan Allah sekaligus dengan sesama manusia.

\footnotetext{
${ }^{40}$ Ibid., 50-51.

${ }^{41}$ Muhammad Roqib, Prophetic Education: Kontekstualisasi Filsafa ..., 125-126.

${ }^{42}$ Masnur Muslih, Pendidikan Karakter: Menjawab Tantangan Multidimensional (Jakarta: Bumi Aksara, 2011), 76.

${ }^{43}$ Hujair AH. Sanaky, Paradigma Pendidikan Islam..., 5.
} 


\section{Tujuan Pendidikan Islam Berbasis Ilmu Sosial Profetik}

Tujuan pendidikan Islam berbasis ilmu sosial profetik tidak lepas dari nilai-nilai Al-Qur'an dan Sunnah, yang memandang manusia sebagai 'khalifatullah fi al-ard seperti dalam Q.S Al-Baqarah [2]: 30, manusia sebagai 'abdullāh seperti dalam Q.S. Aż-żāriyāt [51]: 56, dan manusia sebagai insān kāmil, yaitu dalam Q.S. At-Tīn [95]: 4. Pada intinya tujuan dari pendidikan Islam berbasis ilmu sosial profetik, sebagaimana nilai profetik (humanisasi, liberasi, dan transendensi), yaitu:

a. Pendidikan Islam yang Humanis

Dalam bahasa agama humanisasi adalah terjemahan dari pada 'amar ma'rüf, makna asalnya yaitu menganjurkan menegakkan kebaikan. Tujuan humanisasi adalah untuk memanusiakan manusia. ${ }^{44}$ Pada dasarnya pendidikan adalah permasalahan kemanusiaan, maka sasaran bidik pertama adalah manusia (antropologi). Pendidikan berwawasan kemanusiaan penelitian ini menampilkan pengertian bahwa pendidikan harus memandang manusia sebagai subjek pendidikan. Karena itu, proses pendidikan berawal dari pemahaman teologis-filosofis tentang manusia, pada akhirnya manusia diperkenalkan akan keberadaan dirinya sebagai khalifah Allah di muka bumi. Namun demikian juga tidak menjadikan manusia sebagai sumber ikatan-ikatan nilai secara muthlak (antroposentris), tetapi sarat akan nilai moral-transendental. ${ }^{45}$

b. Pendidikan Islam yang Membebaskan

Liberasi disini adalah elektisitas tentang model pembelajaran dalam pendidikan Islam. Karena dalam pembelajarannya, tidak boleh ada pemaksaan dan kekerasan. Maka, dengan mengembalikan pemahaman bahwa proses pendidikan Islam yang sering bersifat kaku menjadi lentur dan memunculkan inspirasi untuk melakukan sutau perubahan. ${ }^{46}$ Sebagaimana Islam agama terbuka, pendidikan Islam tidak dapat bersikap dikotomis karena sikap seperti itu hanya menjadikan umat Islam eksklusif. Tampaknya malah perlu menyadari, Islam mewarisi tradisi sejarah warisan peradaban manusia, artinya pendidikan Islam tidak membangun diri dari sebuah vacuum. $^{47}$

c. Pendidikan Islam yang Trasenden

Tujuan pendidikan Islam yang transenden menjadikan dimensi transendental sebagai ruh segala proses pendidikan. Sehingga membentuk sosok peserta didik yang dalam segala aktivitasnya berpegang teguh pada nilai transendensi. Dalam masyarakat nilai transendensi menjadi kebudayaan bagi peserta didik. $^{48}$ Dengan demikian, tauhid berfungsi mentransformasikan setiap peserta didik menjadi manusia yang memiliki sifat-sifat mulia dan

\footnotetext{
${ }^{44}$ Moh. Shofan, Pendidikan Berparadigma Profetik..., 142.

45 Ibid., 305.

46 Ibid., 114

${ }^{47}$ Kuntowijoyo, Paradigma Islam Interprestasi Untuk. Aksi.., 290.

48 Ibid., 289.
} 
komitmen kepada penegakan kebenaran dan keadilan. Berbagai atribut manusia tauhid diharapkan lahir dari pendidikan Islam. Dalam pendidikan Islam yang transenden, pengkajian ilmu adalah ilmu integralistik, diharapkan akan menyelesaikan konflik sekularisme ekstrem dan agama radikal dalam banyak sektor. ${ }^{49}$

Dengan nilai humanisasi pendidikan Islam menekankan pentingnya memanusiakan manusia dalam prosesnya dengan nilai liberasi juga mendorong membebasan terhadap berbagai bentuk determinisme kultural dan struktural, dengan nilai transendensi perubahan diberikan seutuhnya lebih maknawi, yaitu perubahan yang tetap berada dalam bingkai kemanusiaan dan juga ketuhanan. Digambarkan sebagaimana berikut:

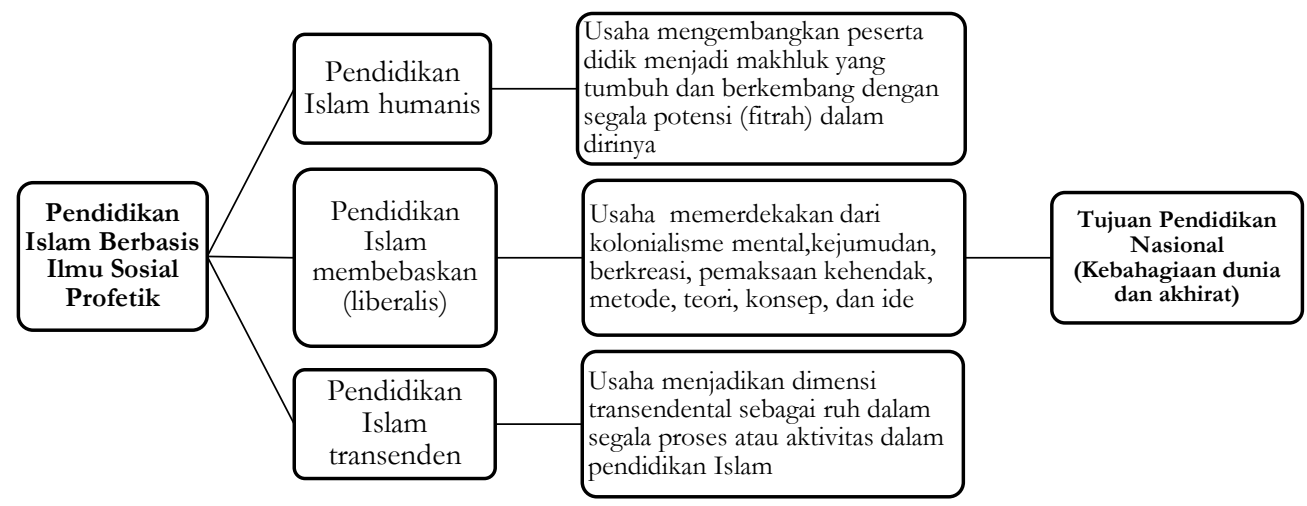

\section{Kurikulum, Metode, Pendidik, Peserta Didik dan Evaluasi Pendidikan Islam Berbasis Ilmu}

\section{Sosial Profetik}

Kurikulum haruslah bersifat fleksibel dan dinamis sesuai dengan konteks, nilai-nilai dan kekuatan sosial. Maka, kurikulum tidaklah bersifat abadi, tetapi akan dapat berubah dikarenakan berbagai hal, seperti: tujuan pendidikan yang tidak sesuai lagi atau keadaan masyarakat yang berubah. Karena setidaknya, kurikulum memuat unsur tujuan, bahan pelajaran, proses belajar-mengajar dan penilaian. ${ }^{50}$ Disain kurikulum pendidikan Islam berbasis profetik berorientasi pada kemampuan mengetahui cara beragama yang benar, mempelajarai Islam sebagai pengetahuan.

Materi pendidikan Islam berbasis ilmu sosial profetik perlu dikemukakan tentang nilai strategis. Materi (MI) adalah dengan mengenal huruf dan membaca teks, kemudian (MTs) dapat dikembangkan materi dengan keterampilan atau strategi membaca cepat dan juga kreativitas menulis, sedangkan tingkah (MA) dikembangkan teknik memanfaatkan bahasa dan baca tulis untuk berkomunikasi efektif. Untuk keseluruhan tingkat, perintah membaca secara luas adalah perintah belajar bahasa termasuk bahasa Asing. ${ }^{51}$

\footnotetext{
${ }^{49}$ Kuntowijoyo, Islam sebagai Ilmu..., 55.

${ }^{50}$ Nasution, Pengembngan Kurikulum (Bandung: Citra Aditya, 1993), 3-4.

${ }^{51}$ Ibid., 132.
} 
Metode diartikan juga sebagai cara yang digunakan oleh pendidik untuk mencapai tujuan yang dikehendaki. ${ }^{52}$ Dalam rangka mencapai tujuannya, pendidikan Islam berbasis ilmu sosial profetik menggunakan metode, sebagai berikut: ${ }^{53}$ metode Hiwär Qur'äni dan Nabawi, mendidik dengan cara amtsäl Qur'äni dan Nabawi, mendidik dengan memberi teladan, mendidik dengan pembiasaan diri dan juga pengalaman, mendidik dengan latihan dan pengalaman, mendidik menggunakan íbrah (pelajaran) dan mau'izah (peringatan), dan mendidik menggukan targhib dan tarbib. Dapat menggunakan metode yang disebut "edutainment" atau pendidikan menyenangkan yang memberikan kesempatan kepada peserta didik untuk terlibat dan menikmati proses pembelajaran dalam suasana kondusif dengan proses pembelajaran yang rileks, menyenangkan, tidak menegangkan dan bebas dari tekanan baik itu fisik ataupun psikis. ${ }^{54}$ Dan juga menggunakan teori Quantum, berisi teknik yang sangat praktis untuk memunculkan potensi belajar peserta didik. ${ }^{55}$

Dalam proses pendidikan Islam berbasis profetik pendidik berperan besar dan strategis. Secara umum tugas pendidik mengupayakan perkembangan seluruh potensi peserta didiknya. Pendidikan Islam berbasis profetik bukan sekedar mentransfer ilmu tetapi yang lebih tinggi dari itu adalah mentransfer nilai-nilai (transfer of knowledge and values) ajaran Islam dengan semangat profetik. Pendidik adalah pembawa amanah ilahiah bertugas mencerdaskan kehidupan umat dan membawanya taat beribadah dan berakhlak mulia. ${ }^{56}$ Sedangkan Peserta didiknya terkait dengan pandangan wahyu tentang hakikat dari manusia. Dimana setiap peserta didik memiliki potensi yang positif (fitrah) sebagai dasar perkembangan manusia. ${ }^{57}$ Peserta didik harus mampu mengembangkan potensi fitrahnya seumur hidup (long life education). Konsep pendidikan seumur hidup bertumpu kepada kenyataan bahwa belajar harus dilakukan seumur hidup manusia. ${ }^{58}$

Evaluasi menggunakan tes dan non-tes. Selain bisa dievaluasi dengan tes dan non-tes, seperti dari catatan harian yang memuat ibadah, pergaulan peserta didik dengan teman, dengan guru, dan lingkungan pendidikan, juga aktivitas lain yang positif baik berupa prestasi dalam sekolah (formal) maupun luar sekolah (non-formal) sebagai pertimbangan dalam penilaiannya. ${ }^{59}$ Pendidikan Islam berbasis profetik memberikan konstribusi dalam evaluasi dengan memberikan penilaian terhadap peserta didik sesuai dengan kemampuan dan tingkah laku, maksudnya melakukan penilaian secara objektif.

\footnotetext{
52 Abdul Majid dan Yusuf Mudzakar, Ilmu Pendidikan Islam (Jakarta: Kencana Pranada Media, 2006), 165

${ }^{53}$ Khoiron Rosyadi, Pendidikan Profetik..., 218-237.

${ }^{54}$ Hamruni, Konsep Edutainment dalam Pendidikan Islam (Yogyakarta: Bidang Akademik UIN Sunan Kalijaga, 2008), 8-10.

${ }^{55}$ Hamruni, Edutainment Dalam Pendidikan Islam dan Teori-teori Pembelajaran Quantum (Yogyakarta: Fakultas Tarbiyah UIN Sunan Kalijaga, 2009), 50

56 Zuhairi. Metodik Khusus Pendidikan Agama (Surabaya: Usaha Nasional, 1977), 33.

${ }^{57}$ Ibid, 136

${ }^{58}$ Imam Barnadib dan Sutari Imam Barnadib, Beberapa Aspek Subtansial Ilmu Pendidikan (Yogyakarta: Andi Offset, 1996), 1115.

59 Ibid., 151.
} 
Terkait lembaga Pendidikan berbasis ilmu sosial profetik terdiri dari tiga bagian antara lain: pertama yakni keluarga, Internalisasi nilai fundamental Islam paling efektif dan bermakna berangkat dari pendidikan keluarga. Keluarga memiliki dampak besar dalam pembentukan prilaku anak. Melalui keluarga, anak mendapatkan pendidikan bahasa, nilai, norma. Ayah sangat besar siksaannya pada hari kiamat, apabila keluarganya bodoh pengetahuan agama Islamnya. ${ }^{60}$ Terdapat kewajiban keluarga terkait anak. Pertama, bertanggung jawab terkait ketenangan, cinta kasih, kedamaian dalam rumah dan menghilangkan segala kekerasan, kebencian. Kedua, keluarga mengawasi proses-proses pendidikan; kedua, Masjid. Nabi Muhammad melakukan dakwah dan pendidikan pertama kali yaitu melalui masjid. ${ }^{61}$ Pada awal penyebaran Islam, masjid digunakan sebagai markas besar dari tentara dan pusat pembebasan umat dari penghambaan manusia pada manusia, berhala atau țăghüt. Masjid pun digunakan sebagai tempat pendidikan yang mengajak kepada keutamaan, kecintaan pada pengetahuan, kesadaran sosial, pengetahuan mengenai hak dan kewajiban terhadap Islam, pada dasarnya didirikan untuk mewujudkan ketaatan pada syariat, keadilan serta rahmat Allah; ${ }^{62}$

Ketiga, Masyarakat. Masyarakat harus menjadi penyeru kebaikan (humanisasi) dan juga melarang kemungkaran (liberasi), masyarakat harus dapat membina lingkungan dengan saling membantu dan mengingatkan, dapat dilakukan juga melalui kerja sama, masyarakat harus memiliki sikap tanggung jawab dan saling mencintai, mampu menanamkan nilai transendental dan menyediakan tempat pendidikan dan sebagai sumber pembelajaran (laboratorium pendidikan); ${ }^{63}$ keempat, Sekolah. Sekolah sebagai media realisasi pendidikan berdasrakan tujuan pemikiran, akidah dan syariat demi terwujudnya penghambaan pada Allah dan mengembangkan segala potensi sesuai fitrahnya sehingga terhindar dari berbagai penyimpangan. Adapun fungsinya: ${ }^{64}$ sebagai penyucian serta pembersihan pemikiran peserta didik dari berbagai macam faham-faham yang salah, memperluas wawasan dan pengalaman melalui transfer ilmu dan nilainilai serta budaya, mewujudkan keterikatan, integrasi, hegemoni, keharmonisan antar peserta didik, sarana saling mengenal (li ta'ârofu), dan membantu penyempurnaan tugas keluarga dalam pendidikan anak.

\footnotetext{
${ }^{60}$ Ali Hasan Az-Zhecolany, Kesalahan-Kesalahan Orang Tua Penyebab..., 55

${ }^{61}$ Mohammad Roqib, Prophetic Education, Kontekstualisasi Filsafat..., 194.

62 Abdurrahman An-Nahlawi, Pendidikan Islam di Rumah, Sekolah, dan Masyarakat (Jakarta: GIP, 1995), 137.

${ }^{63}$ Ibid., 180-183.

64 Ibid., 152-160.
} 


\section{Relevansi Pendidikan Islam Berbasis Ilmu Sosial Profetik Terhadap Pengembangan} Kurikulum 2013

Terkait dengan relevasi sebagaimana dimaksud, terdapat beberapa relevansi yang ada pada kurikulum 2013, antara lain:

\section{Relevansi Terhadap Karakteristik Kurikulum 2013 di Madrasah}

Relevansi mengembangkan keseimbangan pengembangan sikap spiritual, sosial. Dalam pendidikan Islam berbasis profetik landasan yang digunakan (humanisasi, liberasi, dan transendensi). Sebagaimana profetik sendiri diambil dari ISP (ilmu sosial profetik) pemikiran kuntowijoyo, dimana menghendaki adanya transformasi menuju transendensi melalui proses humanisasi ('amar ma'rüf) liberasi (nahyi mungkar) dan didasarkan pada transendensi (iman kepada Allah). ${ }^{65}$ kemudian dari prinsip pendidikan Islam berbasis ilmu sosial profetik, akan lebih dekat dengan ruh spiritual yang menjadi kandungannya, tanpa mengindahkan unsur keduniaaan serta kemanusiaan. ${ }^{66}$ Dalam hal ini nampak adanya kerja sama seimbang antar peserta didik, sebagaimana peran kurikulum 2013 bagi madrasah. Dengan demikian memiliki karakter yang sama yaitu keseimbangan sikap spiritual dan sosial, rasa ingin tahu, kreativitas, kerja sama yaitu dengan kemampuan intelektual serta psikomotorik. Dalam hal ini terwujud dalam nilai-nilai profetik.

Sebagaimana masyarakat dalam pendidikan berbasis ilmu sosial profetik, yaitu: ikut berperan mendirikan, membiayai lembaga pendidikan (sekolah, madrasah, pesantren), ikut berperan serta dalam mengawasi pendidikan, menyediakan tempat pendidikan dan sebagai sumber pembelajaran anak. ${ }^{67}$ Maka, memiliki relevansi dalam menjadikan masyarakat sebagai sumber belajar dan menjadikan madrasah sebagi bagian dari masyarakat. Terkait kompetensi dan karakter, kompetensi pendidikan Islam berbasis ilmu sosial profetik membentuk generasi muslim yang berdimensi (kompetensi) transenden, humanis, liberalis. Dalam kurikulum 2013 adalah sikap, pengetahuan, dan keterampilan. Kemudian transfer ilmu pengetahuan dan nilai-nilai (values) yang terkandung di dalamnya agar menjadikan peserta didik memiliki karakter amar ma'rüf dan nabyì mungkar serta iman pada Allah.

\section{Relevansi Terhadap Orientasi Kurikulum 2013 di Madrasah}

Berdasarkan Permendikbud pada tahun 2013, pengembangan kurikulum 2013 sudah melalui proses yang panjang dan telaah agar sebelum disampaikan pada publik dapat memberikan pandangan lebih sempurnah. Adapun orientasi pengembangan kurikulum 2013 adalah tercapainya kompetensi

\footnotetext{
${ }^{65}$ Kuntowijoyo, Paradigma Islam Interprestasi Untuk, Aksi..., 291.

${ }^{66}$ Muslih dan Aden Wijdan, pendidikan Islam Dalam Peradaban..., 12. Baca juga Muslih, Muslih, and Miftachul Ulum. "Pendidikan Islam Antara Dua Atap: Studi Pada Kebijakan Pendidikan Islam Di Sekolah Dan Madrasah". Mudir : Jurnal Manajemen Pendidikan 1, no. 2 (July 27, 2019): 48-65. Accessed August 31, 2021. http://ejournal.insud.ac.id/index.php/MPI/article/view/85.

${ }^{67}$ Hazbullah, Dasar-dasar Pendidikan Islam.... 99.
} 
yang seimbang baik, sikap (attitude), keterampilan (skill), dan pengetahuan (knowledge). Adapun relevansi ketiga kompetensi tersebut, yaitu:

a. Standar kompetensi lulusan (sikap) dalam kurikulum 2013 di madrasah

Setelah menganalisis terkait kompetensi sikap baik jenjang madrasah Ibtidaiyah (MI), Tsanawiyah (MTs), dan Aliyah (MA), baik kurikulum 2013 madrasah maupun pendidikan Islam berbasis profetik, maka peneliti menyimpulkan adanya relevansi (kesesuaian) diantara keduanya tersebut. Dimana standar kompetensi lulusan aspek sikap dalam kurikulum 2013 madrasah relevan dengan sikap-sikap yang ada dalam pendidikan profetik, dari aspek transedensi akan menciptakan manusia yang beriman, berakhlak mulia, dan percaya diri. Aspek liberasi dan humanisasi yang menciptakan manusia bertanggung jawab dalam berinteraksi secara lingkungan sosial dan alam sekitar dan juga dalam bercaturan masyarakat global.

b. Standar kompetensi lulusan (pengetahuan) dari kurikulum 2013 di madrasah

Relevansinya terkait dimensi pengetahuan baik jenjang MI, MTs, maupun MA. Menginginkan sumber daya manusia (output) yang berpengetahuan dan wawasan luas baik teknologi, seni serta budaya dalam segi kemanusiaan, kebangsaan, kenegaraan, dan peradaban. Karena dalam kompetensi pengetahuan kurikulum 2013 di madrasah terdapat pula nilai profetik di dalamnya, (humanisasi: memiliki pengetahuan faktual, konseptual, prosedural, metakognitif), (liberasi: dalam ilmu pengetahuan, teknologi, seni, budaya), (transendensi: dengan wawasan kemanusiaan, kebangsaan, kenegaraan, peradaban terkait penyebab, dampak fenomena dan kejadian).

c. Standar kompetensi lulusan (keterampilan) kurikulum 2013 di madrasah

Relevansinya dari aspek keterampilan, pada intinya yaitu memiliki tujuan akhir sebagai individu yang memiliki kemampuan baik berupa pikiran maupun tindakan yang efektif dan kreatif, sehingga bisa mengaplikasikan apa yang didapatkan peserta didik di madrasah ke masyarakat (kontributif). Pendidikan Islam berbasis ilmu sosial profetik memandang setiap manusia memiliki potensi masing-masing, sehingga harus dikembangkan melalui berpikir dan bertindak baik secara efektif maupun kreatif dan inovatif. Adapun relevansi integrasi dilihat dari standar kompetensi yang ditetapkan pemerintah dalam kurikulum 2013 yang berupa sikap sesuai pendidikan Islam yang transenden, keterampilan sesuai dengan pendidikan Islam yang membebaskan, dan pengetahuan sesuai dengan pendidikan Islam yang humanis.

\section{Relevansi Terhadap Komponen Kurikulum 2013 di Madrasah}

Terkait dengan relevansi pendidikan Islam berbasis ilmu sosial profetik dengan komponen kurikulum 2013, yakni pada tujuan kurikulum 2013, materi pembelajaran, model pembelajaran dan evaluasi pembelajaran pada kurikulum 2013. Berikut uraiannya: 
a. Tujuan kurikulum 2013 di madrasah

Secara garis besar tujuan modernisasi pendidikan Islam berbasis ilmu sosial profetik relevan dengan tujuan kurikulum 2013 madrasah. Baik terkait dengan tujuan Pendidikan nasional tahun 2013 maupun tujuan kurikulum 2013 madrasah sendiri. Pada intinya adalah menciptakan pendidikan Islam yang lebih baik dengan mengalih potensi yang dimiliki peserta didik (humanisasi), sehingga madrasah menghasilkan output yang kompeten dan berkualitas (intelek-ulama) dimana lulusan madrasah akan mampu bersaing dalam percaturan masyarakat global yang terus berkebang (liberasi). Lebih lagi menjadi Insan beriman dan bertakwa kepada Allah (transendensi).

b. Materi pembelajaran kurikulum 2013 di madrasah

Sebagaimana materi pembelajaran dalam kurikulum 2013 (madrsah) yaitu materi pembelajaran bersifat tematik. ${ }^{68}$ Pendidikan Islam berbasis ilmu sosial profetik pun demikian yaitu adanya integrasi ilmu pengetahuan terkait materi yang disusun ataupun diajarkan. Secara keseluruhan terdapat relevansi, antara lain: Humanisasi yaitu materi pembelajaran disusun berdasarkan usia dan tingkat kemampuan belajar. Liberasi yaitu adanya perhatian penyusunan materi pembelajaran baik dari aspek ekonomi, sosial, budaya, politik, dan ideologi. Transendensi yaitu materi pembelajaran mengarahkan ke arah pendidikan jasmani dan rohani, dunia dan akhirat, serta material dan spiritual.

c. Model pembelajaran kurikulum 2013 di madrasah

Relevansinya dimana dalam pembelajaran haruslah meningkatkan keseimbangan hardskills dan soft-skills yang mengutamakan pembudayaan dan pemberdayaan peserta didik dirancang menyenangkan bukan membuat tertekan (humanisasi). Dalam proses pembelajaran pendidik menjadi fasilitatornya, sehingga peserta didik mempunyai waktu memunculkan potensi. Adanya pemanfaatan teknologi untuk meningkatkan efektivitas proses pembelajaran (liberasi). Pembelajaran dilaksanakan dengan menanamkan nilai-nilai (spiritual) dan memberikan keteladanan, membangun kemauan, mengembangkan kreativitas (transendensi). Sejalan dengan prinsip pembelajaran, kurikulum 2013 di madrasah pembelajaran berpusat pada pendidik menjadi pembelajaran berpusat pada peserta didik (student centered), ${ }^{69}$ Dimana menjadikan peserta didik sebagai subjek sekaligus objek dari pembelajaran sendiri.

d. Evaluasi pembelajaran kurikulum 2013 di madrasah

\footnotetext{
${ }^{68}$ Kemendikbud, Paparan Wakil Menteri Pendidikan dan Kebudayaan R.I Bidang Pendidikan, Konsep dan Implementasi Kurikulum 2013, Jakarta 14 Januari 2014, 26.

${ }^{69}$ Ahmad Aprillah, Pelaksanaan Kurikulum 2013 dan Kesiapan Guru, academia. Edu.com, diakses tanggal 16 Juni 2014.
} 
Dalam kurikulum 2013 di madrasah, evaluasi pembelajaran diarahkan mengukur hasil pencapaian kompetensi p setelah mengikuti pembelajaran. ${ }^{70} \mathrm{Hal}$ tersebut relevan dengan evaluasi pendidikan Islam berbasis ilmu sosial profetik, pada intinya hasil pembelajaran dimana peserta didik mampu melaksanakan yang sudah diketahuinya dari proses pembelajaran, kemudian penilaian tidak hanya subjektif tapi lebih objektif dengan melihat proses yang diikuti peserta didik dalam pembelajarannya, ataupun tingkah lakunya dalam lembaga pedidikan (madrasah). Kurikulum 2013 madrasah menggunakan evaluasi pembelajaran yaitu dengan penilaian-penilaian sebagai berikut: Authentic Asessment: penilaian pada input, proses serta output. ${ }^{71}$ Sebagaimana juga dengan evaluasi dalam pendidikan Islam berbasis profetik yang menjadikan proses sebagai salah satu acuan dalam memberikan penilaian. Hal tersebut dimaksudkan agar dapat mendapatkan hasil objektif (otentik) dalam mengevaluasi hasil pembelajaran.

\section{Implikasi Pendidikan Islam Berbasis Ilmu Sosial Profetik Terhadap Pengembangan Kurikulum 2013 di Madrasah}

Untuk memperoleh gambaran secara terperinci terkait implikasi profetik terhadap pengembangan kurikulum 2013 PAI di madrasah, maka dalam hal ini akan mengfokuskan penelitian pada implikasinya terhadap komponen-komponen kurikulum PAI yang meliputi: tujuan, isi kurikulum, proses pembelajaran dan evaluasi pembelajaran, sebagaimana berikut:

a. Tujuan Kurikulum 2013 di Madrasah

Ada dua tujuan kurikulum 2013 di madrasah antara lain: pertama, tujuan pendidikan agama Islam (PAI) diorientasikan kepada upaya memberikan keterampilan dan alat-alat pada peserta didik yang dapat dipergunakan berinteraksi dengan lingkungan yang selalu berada dalam proses perubahan, sehingga bersikap dinamis dalam merespon tuntutan dan kebutuhan lingkungannya, sehingga mampu menyesuaikan dan melakukan penyesuaian kembali dengan tuntutan perubahan sosial dan perkembangan IPTEK dilandasi oleh nilai-nilai kebenaran; ${ }^{72}$ kedua, Bertujuan meningkatkan kepedulian dan kesadaran peserta didik akan masalah-masalah yang dihadapi oleh umat manusia yang merupakan bagian dari kewajiban dan tanggung jawab untuk memecahkan melaui da'wah bi al-hăl, baik yang terkait masalah sosial, ekonomi, politik, dan budaya ataupun lainnya. ${ }^{73}$

\footnotetext{
${ }^{70}$ Kementerian Agama RI, Pedoman Teknis Implementasi..., 70-72.

${ }^{71}$ Muhammad Zaini, Pengembangan Kurikulum (Yogyakarta: TERAS, 2009), 143-144.

${ }^{72}$ Muhaimin, Pengembangan Kurikulum Pendidikan Agama Islam...,. 129.

${ }^{73}$ Ibid., 135.
} 
Implikasinya terhadap tujuan kurikulum 2013 PAI madrasah adalah menekankan pengembangan kompetensi dan pendidikan karakter dengan nilai profetik (humanisasi, liberasi, transendensi). Maka menjadi kompetensi sikap, pengetahuan, keterampilan yang humanis, liberalis dan trasendental. Pendidikan karakter dengan nilai-nilai 'amar ma'rüf, nabyz mungkar, imān billah. Sehingga kompetensi dan karakter akan jelas.

b. Isi Kurikulum 2013 di Madrasah

Sebagaimana kurikulum 2013 madrasah standar isi merupakan kriteria mengenai ruang lingkup dari materi serta tingkat kompetensi untuk mencapai kompetensi lulusan pada jenjang dan jenis pendidikan tertentu. Maka ruang lingkup materi dan tingkat kompetensi peserta didik yang harus dicapai pada satuan pendidikan dalam jenjang dan jenis pendidikan tertentu, dirumuskan dalam standar isi untuk setiap mata pelajaran, dalam hal ini mata pelajaran Pendidikan agama Islam (Al-Qur'an-hadis, akidah-akhlak, fikih, dan SKI).$^{74}$ Adapun implikasi dari ilmu sosial profetik terhadap standar isi dari kurikulum 2013 madrasah dalam hal ini mata pelajaran PAI.

1) Madrasah Ibtidaiyah (MI)

Dengan berladaskan nilai humanisasi, liberasi dan transendensi, diharapkan kurikulum 2013 mata pelajaran PAI madrasah akan memberikan konstribusi secara nyata bagi peserta didik (MI) yang merupakan pendidikan dasar dan pondasi bagi pendidikan selanjutnya. Implikasi terhadap jenjang MI, adanya pengembangan hafalan serta pemahaman terkait surat-surat pendek, menyampaikan hadis terkait kehidupan sosialnya, memberikan contoh kongkrit terkait akhlak baik dan buruk, membimbing langsung cara beribadah, dan mempelajari autobiografi para ulama.

2) Madrasah Tsanawiyah (MTs)

Implikasi ilmu sosial profetik terhadap kurikulum 2013 PAI madrasah adalah pada jenjang MTs. Harus terus adanya peningkatan iman, takwa, dan akhlak mulia sebagai bagian transendensi. Kebutuhan kompetensi masa depan yaitu kemampuan berkomunikasi, berpikir kritis dan kreatif toleran dalam keberagaman, mampu hidup dalam masyarakat global dll, sebagai bagian liberasi. Materi kurikulum harus meningkatkan potensi, kecerdasan, dan minat peserta didik, sebagai bagian dari humanisasi.

3) Madrasah Aliyah (MA)

Implikasi ilmu sosial profetik terhadap kurikulum 2013 PAI di madrasah jenjang MA. Harus ada perluasan serta kesesuaian materi terhadap kebutuhan masyarakat, karena diharapakan lulusan madrasah akan bisa bersaing dengan SDM yang lainnya. Adanya

\footnotetext{
${ }^{74}$ Kemenag RI, Peraturan Menteri Agama Republik Indonesia..., 33.
} 
pembudayaan dari nilai-nilai profetik (humanisasi, liberasi, transendesi) pada materi tersebut. Paling penting yaitu mendukung peningkatan iman, takwa, akhlak mulia dan memelihara toleransi antar sesama.

Secara keseluruhan mata pelajaran pendidikan agama Islam haruslah terintegrasi antara sains sosial dengan nilai Islam dimana menjadikan Al-Qur'an sebagai petunjuk prilaku kehidupan, karena pada umumnya semua setuju bahwasanya sebuah teori ilmu-ilmu Islam harus berdasarkan diri pada wahyu. ${ }^{75}$

c. Proses Pembelajaran Kurikulum 2013 di Madrasah

1) Media Pembelajaran

Penerapan media yang digunakan dalam menanamkan nilai-nilai profetik dalam pembelajaran adalah yang berhubungan langsung dengan benda, kejadian, dan keadaan sebenarnya. ${ }^{76}$ Media tersebut dapat bersumber dari kegiatan, pengalaman masyarakat atau bersumber dari sekitarnya, contoh: aktivitas masyarakat. Media pembelajaran PAI dapat menggunakan, mislanya: buku, majalah, surat kabar, audio-visual, praktik ibadah, keteladanan, dan perayaan-perayaan keagamaan, termasuk menghadapkan peserta didik kepada masalah untuk dipecahkan. Dengan demikian profetik memberikan implikasi dimana pendidik (guru) harus bisa memanfaatkan teknologi dengan baik, cerdas, kreatif dan maksimal, yaitu mengenalkan kepada peserta didik ataupun memberikan kesempatan peserta didik untuk bisa berkreasi.

2) Pola Pembelajaran

Implikasi profetik terhadap pembelajaran, yaitu dengan pola pembelajaran satu arah (guru-peserta didik) menjadi pembelajaran yang interaktif (guru-peserta didik-masyarakatlingkungan, sumber lain). Pola pembelajaran terisolasi menjadi jejaring (peserta didik dapat menimba ilmu dari siapa saja dan dari mana saja yang mana dapat diperoleh melalui berbagai media yang ada). Pola pembelajaran pasif menjadi aktif (pembelajaran aktif mencari semakin diperkuat dengan model pembelajaran pendekatan sains). Pola belajar sendiri menjadi berkelompok. Pola pembelajaran alat tunggal menjadi berbasis multimedia. Pola pembelajaran berbasis massal menjadi kebutuhan dengan cara memperkuat pengembangan potensi khusus yang dimiliki, dan pembelajaran ilmu tunggal menjadi ilmu pengetahuan jamak (multidisciplines). ${ }^{77}$

\footnotetext{
${ }^{75}$ Kuntowijoyo, Paradigma Islam: Interpretasi Untuk. Aksi..., 320-321.

76 Mukhtar, Desain Pembelajaran Pendidikan Agama Islam, (Jakarta: Miska Gazali, 2003), 113-115.

77 Muhaimin, Wacana Pengembangan Pendidikan Islam.., 109-115.
} 
Salah satu metode yang dapat diterapkan untuk menanamkan nilai profetik dalam kurikulum 2013 PAI dapat menggunakan strategi pemecahan masalah (problem solving), yaitu motode yang digunakan sebagai jalan melatih peserta didik menghadapi suatu masalah, baik yang timbul dari diri sendiri, keluarga, sekolah, maupun masyarakat, mulai dari masalah paling sederhana sampai kepada masalah paling sulit. ${ }^{78}$ Intinya pembelajaran harus menerapkan prinsip profetik (humanisasi, liberasi, dan transendensi) dengan memperhatikan potensi yang dimiliki oleh setiap peserta didik, dan guru harus menjadi pendidik, pembimbing sekaligus fasilitator pembelajaran yang baik. Selain itu pendidik juga haruslah memberikan kesempatan kepada peserta didik agar bisa mengembangkan dan mengaktualisasikan dirinya.

d. Evaluasi Pembelajaran Kurikulum 2013 di Madrasah

Selama ini guru PAI lebih mengenal model evaluasi acuan norma/kelompok (norm/group referenced evaluation) dan juga evaluasi acuan patokan (criterian referenced evaluation). Dalam pendidikan agama Islam teryata yang dinilai bukan hanya hafalan surat-surat pendek, hafalan rukun shalat dan seterusnya, tetapi apakah shalatnya rajin atau tidak. Di sinilah perlunya memahami model evaluasi acuan etik. Adapun implikasinya terhadap evaluasi pembelajaran, sebagai berikut: ${ }^{79}$

1) Jika yang dites adalah kemampuan dasar (aptitude), maka digunakan adalah evaluasi acuan norma/kelompok

2) Jika yang dites adalah prestasi belajar (achievement), maka digunakan adalah evaluasi acuan patokan (Criretian Referenced Evaluation).

3) Jika yang dites adalah kepribadian (personality), maka digunakan evaluasi acuan etik. Pendidikan agama Islam (PAI) banyak terkait dengan masalah ini.

Dengan menggunakan evaluasi acuan etik ini, diasumsikan bahwa: manusia pada asalanya adalah baik (fitrah), pendidikan berusaha mengembangkan fitrah (aktualisasi), dan bersatunya iman, ilmu serta amal. Selain menggunakan evaluasi di atas, dapat menggunakan evaluasi kegiatan orang lain. Evaluasi terhadap prilaku orang lain harus disertai amar ma'rüf(humanisasi) dan nabyĩ mungkar (liberasi) yaitu mengajar yang baik dan mencegah dari yang mungkar. ${ }^{80}$ Tujuannya untuk memperbaiki tindakan seseorang, bukan mencari aib atau kelemahan dari seseorang.

\footnotetext{
78 Mukhtar, Desain Pembelajaran Pendidikan Agama Islam..., 143. Baca juga Muslih, Muslih. "Pembelajaran Ayat-Ayat Kawniyah Di SMA Trensains 2 Pesantren Tebuireng Jombang.” ISLAMICA: Jurnal Studi Keislaman 12, no. 2 (March 3, 2018): 455-480.

${ }^{79}$ Muhaimin, Pengembangan Kurikulum Pendidikan Agama Islam..., 53.

${ }^{80}$ Abdul majid dan Yusuf Mudzakir, Imu Pendidikan Islam (Jakarta: Kencana, 2008), 216.
} 
Secara keseluruhan, peran ilmu sosial profetik terhadap pengembangan kurikulum 2013 mata pelajaran PAI di madrasah, sebagai berikut: ${ }^{81}$

Pertama, Peran konservatif, melestarikan berbagai nilai budaya sebagai warisan masa lalu. Kurikulum yang dikembangkan memiliki peran menangkal pengaruh yang dapat merusak nilai luhur di masyarakat, sehingga identitas masyarakat akan terpelihara baik. Pada tataran praktisnya, bahwa madrasah sebagai lembaga pendidikan Islam adalah mewariskan nilai-nilai Islam dan budaya masyarakat kepada generasi muda yakni peserta didiknya. Madrasah harus perperan aktif melestasikan budaya berlandaskan nilai transendensi. Sebagaimana misi dari profetik menjadikan transendensi sebagai landasan utamanya, sehingga liberasi dan humanisasi akan melaksanakan peranannya.

Kedua, Peran kreatif, dikembangkan sebagai tanggung jawab terhadap hal baru sesuai tuntutan zaman. Agar peserta didik di madrasah yang identik dengan pendidikan keagamaan bisa berperan aktif dalam segala bidang dan dalam lingkup sosial masyarakat. Karena, pengembangkan kurikulum 2013 madrasah harus mampu menjawab tantangan sesuai dengan perkembangan dan kebutuhan masyarakat yang cepat berubah.

Ketiga, Peran kritis evaluatif, dengan cara mempertimbangkan bahwa tidak setiap nilai atau budaya lama harus tetap dipertahankan jika memang sudah tidak sesuai dengan tuntutan perkembangan masyarakat. Di sini peran kurikulum untuk menyeleksi nilai atau budaya mana yang perlu dipertahankan untuk dimiliki peserta didik. Maka kurikulum haruslah berperan menyeleksi dan mengevaluasi yang bermanfaat untuk kehidupan peserta didik, diharapkan munculnya SDM lulusan madrasah yang berkualitas (ulama yang intelek).

\section{Kesimpulan}

Pendidikan Islam berbasis ilmu sosial profetik adalah transfer knowledge and values untuk mengesakan Allah dilakukan secara kontinyu dan dinamis disertai pemahaman dalam diri manusia terdapat kelebihan dan kelemahan yang menunjukkan adanya campur tangan yang transenden. Pemahaman ini terus berdialog dengan Tuhan yang transenden dan alam secara internal berwujud self-correction atau mubāsabah an-nafs, secara eksternal berwujud 'amar ma'rüf (humanisasi) dan nahyì mungkar (liberasi). Adapun komponennya, yaitu: Prinsip: integrasi, keseimbangan, persamaan dan pembebasan, kontinuitas dan berkelanjutan, kemaslahatan. Urgensi: membentuk karakter berlandaskan nilai transendensi, humanisasi, liberasi. Hakekat: perubahan disertai dengan tujuan, pengembangan pendidikan Islam teosentris-antroposentris, dan dekat dengan ruh spiritual. Tujuan: pendidikan Islam humanis, membebaskan, transenden, serta memandang manusia sebagai insān kāmil

${ }^{81}$ Ibid., 10-11. 
yaitu sosok manusia sebagai 'abdulläh, dan khalifatullah. Kurikulum: menolak dualisme-sekularisme, menonjolkan tujuan agama dan akhlak, menyeluruh kandungannya. Metode: biwār, amtsāl Qur'āniNabawi, keteladan, pembiasaan, 'ibrah-mau'izah, targhib dan tarbib, edutainment, dan Quantum Learning. Pendidik: lebih pada aktualisasi potensi peserta didiknya. Peserta didik: haruslah mampu mengembangkan potensi fitrahnya tersebut seumur hidup. Evaluasi: menggunakan tes dan non-tes. Dalam evaluasi memberikan penilaian sesuai kemampuan peserta didik. Lembaga pendidikan: keluarga, masjid, masyarakat, dan sekolah.

Relevansi dan implikasi terhadap pengembangan kurikulum 2013 di madrasah, sebagai berikut: pertama, Relevansi terhadap pengembangan kurikulum 2013 madrasah. Berdasarkan karakteristik, orientasi SKL tiap jenjang pendidikan dan komponen kurikulum 2013 di madrasah. Adapun relevansinya adalah pendidikan Islam yang transenden, membebaskan, humanis relevan dengan pendidikan sikap, keterampilan, dan pengetahuan. Karena terdiri atas sikap penuh penghormatan, saling percaya, peduli dan penuh perhatian, ikhlas, saling percaya, pengembangan spiritual serta sosial, menjadikan madrasah sebagai tempat belajar dan juga menjadikan masyarakat sebagai sumber pembelajaran, mengembangkan sikap, pengetahuan, keterampilan, memberi waktu cukup untuk mengembangkan sikap, pengetahuan, dan keterampilan yang bermanfaat bagi peserta didik.

Implikasinya terhadap pengembangan kurikulum 2013 di madrasah, lebih mengfokuskan terhadap komponen kurikulum 2013 PAI yang meliputi: a. Tujuan: menekankan pengembangan kompetensi sikap, pengetahuan, keterampilan secara holistik dan pendidikan karakter dengan tiga nilai profetik menjadi kompetensi sikap, pengetahuan, keterampilan yang humanis, liberalis dan trasendental. Pendidikan karakter dengan nilai-nilai 'amar ma'rūf, nabyĩ mungkar dan immän billab; b. Isi Kurikulum: haruslah terintegrasi antara sains-sosial dengan nilai-nilai Islam dimana menjadikan AlQur'an sebagai petunjuk teori serta prilaku kehidupan; c. Proses Pembelajaran: Pembelajaran harus menerapkan prinsip profetik (humanisasi, liberasi, transendensi) dengan memperhatikan potensi yang dimiliki oleh setiap peserta didik, dan guru harus menjadi pendidik, pembimbing dan fasilitator pembelajaran; d. Evaluasi: menggunakan evaluasi acuan etik, evaluasi kegiatan orang lain, dan evaluasi sumatif, dengan asumsi bahwa setiap peserta didik pasti memiliki kemampuan tumbuh dan berkembang lebih maju dan meningkat secara berkelanjutan.

\section{Daftar Kepustakaan}

Abdullah, Amin Studi Agama: Normavitas atan Historitas, Yogyakarta: Pustaka Pelajar, 2002.

Abrasyi, al-Attiyah, Dasar-Dasar Pokok Pendidikan Islam, terj. Bustami A. Ghani dan Djohar Bhary, dari judul asli al-Tarbiyah al-Islamiyah, cet. II, Jakarta: Bulan Bintang, 1974. 
Assegaf, Abd. Rachman, Filsafat Pendidikan Islam: Paradigma Pendidikan Hadhari Berbasis IntegratifInterkonektif, Jakarta: Raja Grafindo Persada, 2011.

Azra, Azyumardi, Paradigma Baru Pendidikan Nasional, Rekonstruksi dan Demokratisasi, Jakarta: Buku Kompas, 2002.

Barnadib Imam, Beberapa Aspek Subtansial Ilmu Pendidikan, Yogyakarta: Andi Offset, 1996. , Ilmu Pendidikan Sistematis, Yogyakarta: FIP IKIP, 1982.

Departemen Agama RI, Al-Qur'an dan Terjemahnya, Jakarta Timur: CV. Darus Sunnah, 2002.

Direktur Pendidikan Madrasah, Modul Inti Panduan Pengembangan Kurikulum Madrasah 2013, Jakarta: KEMENAG RI, 2014.

Direktoras Jendral Pendidikan Islam, Nomor 2676 tahun 2013, tentang Kurikulum Madrasah 2013 Mata Pelajaran PAI dan Bahasa Arab Madrasah, Jakarta: Direktorat Jedral Pendidikan Islam, 2013.

Hamalik, Oemar Kurikulum dan Pembelejaran, Jakarta: Bumi Aksara, 1994.

Ismail, Faisal, Masa Depan Pendidikan Islam di Tengah Kompleksitas Tantangan Modernitas, Jakarta: PT. Bakti Aksara Persada, 2003.

Jalaluddin dan Usman, Filsafat Pendidikan Islam: Konsep dan perkembangan, Jakarta: Raja Grafinbdo Persada, 1999.

Jalaluddin Rakhmat, Islam Aktual: Refleksi Sosial Seorang Cendekiawan Muslim (Bandung: Mizan, 1992), hlm. 97.

Kaelany, Islam \& Aspek-Aspek Kemasyarakatan, Jakarta: Bumi Aksara, 2000.

Karim, M. Rusli, Pendidikan Islam Sebagai Upaya Pembebasan Manusia, cet. I, Yogyakarta: Tiara Wacana, 1991.

Kemendikbud, Dokumen Kurikulum 2013, Jakarta: Kementerian Pendidikan dan Kebudayaan, 2012. Paparan Wakil Menteri Pendidikan dan Kebudayaan R.I Bidang Pendidikan, Konsep dan Implementasi Kurikulum 2013, Jakarta 14 Januari 2014.

Kementerian Agama RI, Pedoman Teknis Implementasi Kurikulum Madrasah Untuk MI/MTs/MA/MAK, Cet. ke-I, Jakarta: Direktorat Pendidikan Madrasah-Direktorat Pendidikan Islam, 2014.

Nomor 165 Tahun 2014, tentang Pedoman Kurikulum Madrasah 2013 Mata Pelajaran

PAI dan Bahasa Arab di Madrasah, Jakarta: Direktorat Jedral Pendidikan Islam, 2014.

Kuntowijoyo, Islam Sebagai Ilmu, Jakarta: Teraju Mizan, 2005.

, Islam Sebagai Ilmu: Epistimologi, Metodologi, dan Etika, Yogyakarta: Tiara Wacana, 2006. , Muslim Tanpa Masjid, Esai-Esai Agama, Budaya, dan Politik dalam Bingkai Struktualisme Transendental, Bandung: Mizan, 2001. 
, Muslim Tanpa Masjid, Jakarta: Mizan, 2001.

, Paradigma Islam Interprestasi Untuk, Aksi, Bandung: Mizan, 1994.

Langgulung, Hasan Pendidikan Islam Dalam Abad ke 21, Jakarta: Pustaka Al-Husna Baru, 2003.

Majid, Abdul dan Mudzakir, Yusuf Ilmu Pendidikan Islam, Jakarta: Kencana, 2008.

Menteri Agama Republik Indonesia, Peraturan Menteri Agama Republik Indonesia, No. 000912 Tabun 2013: Tentang Kurikulum Madrasah 2013 Mata Pelajaran Pendidikan Agama Islam dan Bahasa Arab, Jakarta: MENAG RI, 2013.

Peraturan Menteri Agama Republik Indonesia Nomor 000912 Tabun 2013, Jakarta:

Kemenag RI, 2013.

, Pengembangan Kurikulum Pendidikan Agama Islam di Sekolah, Madrasah, dan Perguruan

Tinggi, Jakarta: Raja Grafindo, 2012.

Mulayasa, Guru dalam Implementasi Kurikulum 2013, Bandung: Remaja Rosdakarya, 2014.

Pengembangan dan Impelmentasi Kurikulum 2013, Bandung: Remaja Rosdakarya, 2016.

Muslih, Muslih. "Pembelajaran Ayat-Ayat Kawniyah Di SMA Trensains 2 Pesantren Tebuireng Jombang.” ISLAMICA: Jurnal Studi Keislaman 12, no. 2 (March 3, 2018): 455-480.

Muslih, Muslih, and Miftachul Ulum. "Pendidikan Islam Antara Dua Atap: Studi Pada Kebijakan Pendidikan Islam Di Sekolah Dan Madrasah”. Mudir : Jurnal Manajemen Pendidikan 1, no. 2 (July 27, 2019): 48-65. Accessed August 31, 2021. http://ejournal.insud.ac.id/index.php/MPI/article/view/85.

Nata, Abbudin, Kapita Selekta Pendidikan Islam, Jakarta: Raja Grafindo, 2011. Sosiologi Pendidikan Islam, Jakarta: Rajawali Press, 2014.

Rahman, Fazlur, Islam dan Modernitas Tentang Transformasi Intelektual, terj. Ahsin Muhammad, Bandung: Pustaka Pelajar, 1995.

Ramayulis, Ilmu Pendidikan Islam, Jakarta: Kalam Mulia, 2011.

Roqib Mohammad. dan Nurfandi, Kepribadian Guru: Upaya Mengembangkan kepribadian Guru yang Sehat di Masa Depan, Yogyakarta: Grafindo dan STAIN Press, 2009.

Prophetic Education: Kontekstualisasi Filsafat dan Budaya Profetik dalam Pendidikan, Purwokerto: STAIN Press, 2011.

Rosyadi, Khoiron, Pendidikan Profetik, Yogyakarta: Pustaka Pelajar, 2009.

Sanaky, Hujair AH, Paradigma Pendidikan Islam: Membangun Masyarakat Madani Indonesia, Yogyakarta:

Safiriah Insania Press, 2003.

Shofan, Mohammad, Pendidikan Pardigma Profetik, Yogyakarta: UMG Gresik, 2004.

Sugiyono, Metodologi Penelitian Pendidikan: Pendekatan kuantitatif, kualitatif, R \& D, Bandung: Alfabeta, 2013. 
Tatag Satria Praja, Muslih

Sukmadinata, Nana Syaodih, Metode Penelitian Pendidikan, Bandung: PT. Remaja Rosdakarya, 2012.

Taruna, Mulyani Mudis, Kesiapan Madrasab Dalam Pelaksanaan Kurikulum 2013, Jurnal at-Taqaddum, Volume 6, Nomor 2, November 2014.

Zaini, Muhammad, Pengembangan Kurikulum, Yogyakarta: TERAS, 2009. 